\title{
The socio-cultural significance of mineral licks to the Maijuna of the Peruvian Amazon: implications for the sustainable management of hunting
}

\author{
Michael P. Gilmore ${ }^{1 *}$ (D), Brian M. Griffiths ${ }^{2}$ and Mark Bowler $3,4,5$
}

\begin{abstract}
Background: The overhunting of wild species is a major threat to biodiversity in the Amazon; yet, managed, sustainable hunting is widely considered part of the solution to conserving wildlife populations. Hunting is both a culturally important activity for Indigenous people and provides an important food source. Mineral licks, a focal point of hunting in Amazonia, are naturally occurring areas in the forest where animals come to obtain essential minerals or clays that are thought to neutralize plant-based alkaloids. We sought to better understand the sociocultural importance of mineral licks to the Maijuna Indigenous group to inform the sustainable management of this habitat and associated wildlife populations.
\end{abstract}

Methods: Semi-structured interviews, focus groups, and participatory mapping were carried out with hunters to assess the significance of mineral licks and their associated animal resources as well as to determine how the relationship that the Maijuna have with mineral licks has changed over time.

Results: Mineral licks are culturally significant and useful to the Maijuna in a variety of ways. Hunters target these areas year-round both during the day and night, and animals killed are consumed for subsistence and sold to generate income. The spatial use of mineral licks across the landscape is determined on the generational family level, with families maintaining exclusive use of selected mineral licks and excluding access by other hunters. The Maijuna also have traditional beliefs for why animals visit mineral licks, which is linked to the traditional Maijuna story of the creation of the first tapir. The relationship that the Maijuna have with mineral licks has changed considerably over time, which is observed through changes in hunting technologies and methods as well as the loss of traditional knowledge and beliefs.

(Continued on next page)

\footnotetext{
*Correspondence: mgilmor1@gmu.edu

'School of Integrative Studies, George Mason University, 4400 University Drive, Fairfax, VA 22030, USA

Full list of author information is available at the end of the article
}

(C) The Author(s). 2020 Open Access This article is licensed under a Creative Commons Attribution 4.0 International License, which permits use, sharing, adaptation, distribution and reproduction in any medium or format, as long as you give appropriate credit to the original author(s) and the source, provide a link to the Creative Commons licence, and indicate if changes were made. The images or other third party material in this article are included in the article's Creative Commons. licence, unless indicated otherwise in a credit line to the material. If material is not included in the article's Creative Commons licence and your intended use is not permitted by statutory regulation or exceeds the permitted use, you will need to obtain permission directly from the copyright holder. To view a copy of this licence, visit http://creativecommons.org/licenses/by/4.0/ The Creative Commons Public Domain Dedication waiver (http://creativecommons.org/publicdomain/zero/1.0/) applies to the data made available in this article, unless otherwise stated in a credit line to the data. 


\begin{abstract}
(Continued from previous page)
Conclusions: Traditional and current Maijuna hunting conventions, in which families maintain exclusive use of selected mineral licks, likely reduce the probability of overexploitation of animal populations. Community-based management plans for mineral licks in Maijuna lands and beyond must incorporate and account for the multiple cultural and economic needs of local communities while also striving toward ecological sustainability. Country-wide strategies to conserving forests and using them sustainably should aim to ensure land tenure for rural peoples and encourage management that incorporates traditional sustainable hunting conventions.
\end{abstract}

Keywords: Mammals, Biodiversity, Wildlife, Traditional ecological knowledge, Ethnoecology, Conservation

\section{Background}

Hunting threatens wild mammal populations in the Amazon basin [1], but is a culturally important activity for Indigenous people and a principle source of food [2]. The largest animal species are typically the most frequently targeted, with the ungulates like lowland tapir (Tapirus terrestris), white-lipped peccary (Tayassu pecari), and red brocket deer (Mazama americana), and the large rodents, paca (Cuniculus paca), usually making up the largest proportion of kills [3]. The larger primates are also widely consumed and are favored by some Indigenous communities [4]. Hunters generally target medium- to large-bodied mammals with shotguns by walking trails during the day or searching with flashlights at night [5].

Most large mammals in Amazonia visit mineral licks. Mineral licks are naturally occurring areas in the forest where animals exhibit geophagical behavior to obtain essential minerals lacking in their diet [6] or clays that relieve indigestion caused by plant-based alkaloids [7]. At undisturbed mineral licks, the ungulates, paca, and ateline primates are the most common visitors $[8,9]$. The relatively high frequency of visits by these soughtafter game species means that mineral licks are prime locations for hunting, and hunting at mineral licks accounts for up to $30 \%$ of all harvested biomass at some sites $[10,11]$. Tapir and white-lipped peccary come from afar to use mineral licks, which means that these vulnerable species can be extirpated from a large area simply by concentrated hunting at these focal points [12].

The Maijuna-Kichwa Regional Conservation Area (MKRCA) is one of the Peruvian Amazon's newest protected areas, comprising 391,039.82 ha of Maijuna Indigenous territory. The Maijuna are one of the smallest and most vulnerable Indigenous groups in Peru [13]. Their ancestral forests sustain and nourish the Maijuna culture, making it critically important to effectively manage and protect the area. In addition to its cultural importance, the MKRCA is one of the most biologically rich places on Earth and an extremely valuable carbon sink [14].

The MKRCA is a powerful example of communitybased conservation. The Maijuna originally conceived the idea for conserving this area, and they pushed relentlessly for its creation. After centuries of being marginalized and disempowered by outsiders, the Maijuna established an Indigenous federation in 2004 focused on conserving their lands and culture [13]. Against steep odds, they successfully fought to end exploitive logging and poaching on their lands in 2009 and, with the help of allies, successfully persuaded the Peruvian Government to create the MKRCA in 2015. The Maijuna are committed to effectively manage the MKRCA and its resources. Of particular interest to the Maijuna are medium- to large-bodied mammals, such as tapir and white-lipped peccary, that were severely overhunted by loggers and poachers until 2009.

Understanding the socio-cultural importance of mineral licks to the Maijuna, and the way they are currently and traditionally used are the first steps in understanding how wildlife populations are affected by hunting around mineral licks and whether mineral lick management might be a useful strategy in conserving mammal populations and safeguarding food security in rural Amazonia. Such understanding is also required to ensure that any management plans that are ultimately developed for the MKRCA incorporate and account for the multiple cultural and economic needs of the Maijuna while also striving toward ecological stability. Here we assess the significance of mineral licks and their associated animal resources to the Maijuna and document changing relationships between the Maijuna and mineral licks over time.

\section{Methods}

\section{Study area}

The Maijuna, also known as the Orejón, are a western Tucanoan people of the northeastern Peruvian Amazon [13]. Today, there are fewer than 500 individuals living in four Maijuna communities: Puerto Huamán and Nueva Vida along the Yanayacu River, Sucusari along the Sucusari River, and San Pablo de Totoya (Totolla) along the Algodón River (Fig. 1). These three river basins, part of the ancestral territory of the Maijuna, are now within the MKRCA with the headwaters of the rivers in the core of the reserve. No other communities are located within these river basins, which makes supporting and empowering the Maijuna to effectively manage 


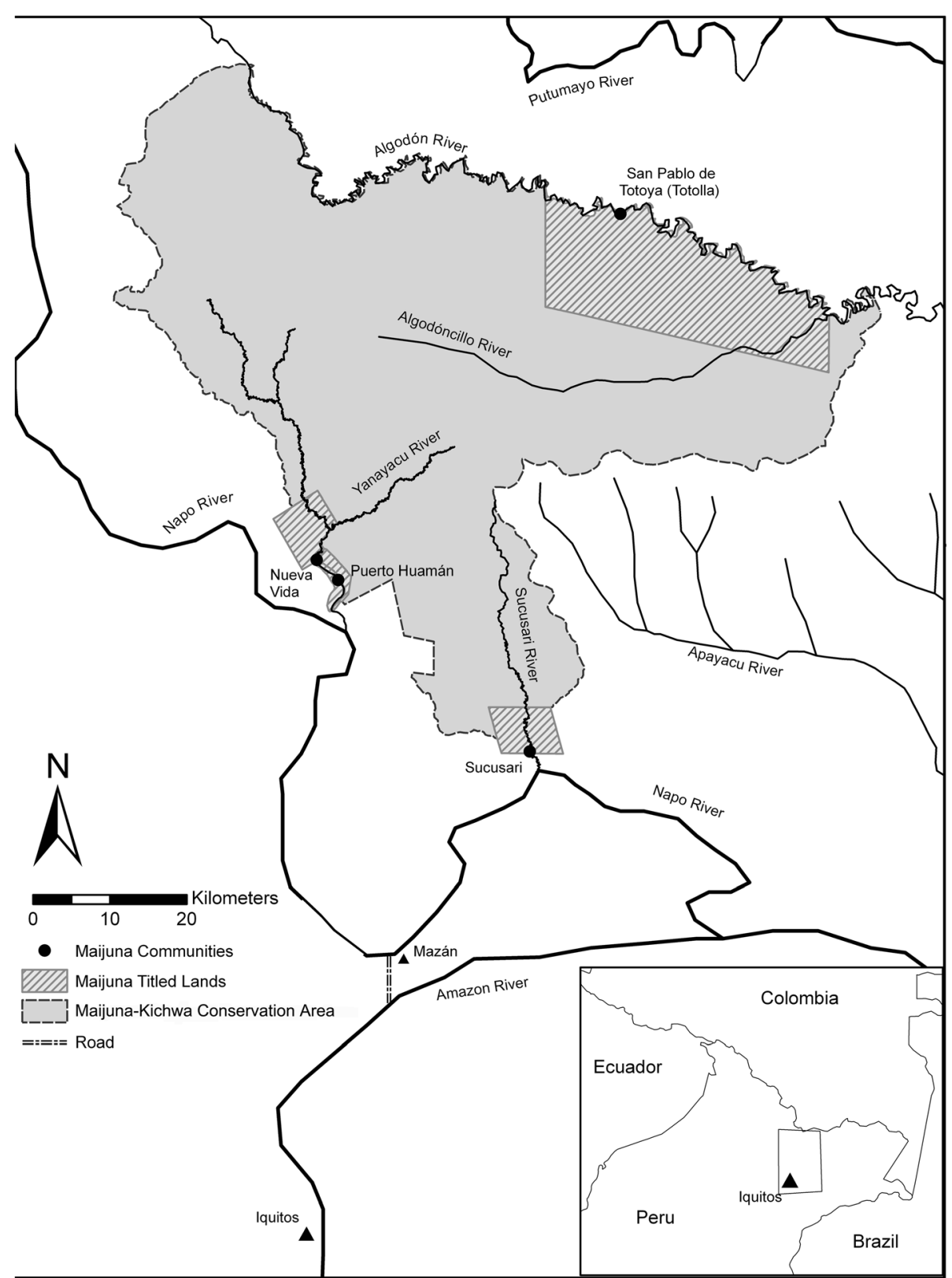

Fig. 1 Map of the study area, including all four Maijuna communities and the Maijuna-Kichwa Regional Conservation Area (MKRCA). All field research was conducted in the Maijuna community of Sucusari

and conserve the MKRCA invaluable to the protection of this immense and extremely biologically and culturally rich area [14].

Data for this study was collected from 1999 to 2019 in the Maijuna community of Sucusari (Fig. 1). This area is approximately $126 \mathrm{~km}$ by river from Iquitos, the capital of the Region of Loreto. However, this trip can be shortened to $70 \mathrm{~km}$ by crossing the thin isthmus between the Napo and Amazon Rivers by road at Mazán, a small town. The Sucusari community has legal title to 4771 ha that adjoins the recently established MKRCA [14]. The community has 166 residents living in 32 monofamilial or plurifamilial households [15]. Within the residents of Sucusari, $59 \%$ are Maijuna, $35 \%$ are mestizos ${ }^{1}$, and the remaining $6 \%$ are Kichwa. The main subsistence activities of community members include hunting, fishing, swidden-fallow agriculture, and gathering of various

${ }^{1}$ Mestizos are people of mixed Amerindian and Iberian descent found throughout the Peruvian Amazon who practice a mixture of traditional agriculture, hunting, fishing, and forest product extraction for their livelihoods ([16-18] as cited in [19]: 421) 
forest products. To support basic household needs, residents sell game meat, domesticated animals, agricultural products, and a variety of non-timber forest products [14]. Game meat and other products are sold within Sucusari and in communities nearby along the Napo River as well as in Mazán and the city of Iquitos.

Sucusari is located in an area dominated by upland tropical rainforest, permeated by rivers that are largely bordered by seasonally inundated floodplain forest [20]. Like much of the central Amazon basin, the terrain is relatively flat, with an elevation varying from 80 to 200 $\mathrm{m}$ above sea level [21]. This region of the Peruvian Amazon is tropical, humid, and warm with a mean annual precipitation of approximately $3100 \mathrm{~mm}$ per year and mean annual temperature of $26^{\circ} \mathrm{C}$ [22].

\section{Data collection and analysis}

Prior informed consent (PIC) was obtained from the Sucusari community as well as from individual research participants before beginning the interviews for this study. From 1999 to 2019, semi-structured interviews [23] were conducted with 24 hunters (mean age $=45.04$; range $=22-70)$ to gather information on the significance of mineral licks and their associated animal resources as well as to document changing relationships between hunters and mineral licks over time. The 24 hunters interviewed represent $45.28 \%$ of all hunters in the Sucusari community during this 20-year time span. Only men hunt in the Maijuna communities, and a hunter was defined as someone who has hunted at least once in their lifetime; however, all hunters interviewed for this study have hunted extensively throughout their lives. Individual interviews were conducted in Spanish or the Maijuna language, the latter with the help of a community leader that is fluent in both.

Additionally, in July 2017, a focus group was conducted with 16 hunters $(55.17 \%$ of hunters in the Sucusari community during this time period; mean age $=42$; range $=22-68)$ to identify the locations of mineral licks in the Sucusari River basin using participatory mapping techniques [24, 25]. Mapped mineral licks were then visited, and their locations marked using a hand-held GPS unit to create an accurate base map of the mineral licks of the Sucusari River basin. During an 11-month period from August 2018 to June 2019, this base map was then used to interview 19 active hunters $(91 \%$ of active hunters in the Sucusari community during this time period; mean age $=41$; range $=22-68)$ on a weekly basis about their hunting routes and the mineral licks that they visited. This map was continually updated during this time period as new mineral licks, trails, streams, and hunting camps were identified and mapped with a GPS. To identify key themes, perceptions, and issues in the data collected, qualitative data were coded, organized, and analyzed using a grounded theory framework based on the methods described by Corbin and Strauss [26].

\section{Results and discussion}

Classification and use of mineral licks

Mineral licks are called tùàrà ${ }^{2}$ (mineral lick) or ónóbi (place of masato) in the Maijuna language and collpa in the local Spanish dialect. Mineral licks are one of dozens of different forest habitat types defined and classified by the Maijuna. They classify forest habitats based on geomorphology, physiognomy, disturbance, indicator plant species, and indicator animal species [20]. According to the Maijuna, mineral licks are found at the base of hillsides in both floodplain and upland forest, have a "face" where animals come to consume soil or drink water, and are poorly drained and muddy areas; all of which follows the Western scientific understanding of these areas as well $[9,28]$. In short, mineral licks are both culturally defined and classified by the Maijuna as is the case in other Indigenous and non-Indigenous communities in the Peruvian Amazon [29, 30].

Mineral licks are culturally and economically important to the Maijuna because a number of game animals visit these sites and hunters target these areas yearround for hunting. These mammal and bird species are either diurnal or nocturnal; therefore, Maijuna hunters target mineral licks both day and night revealing an important temporal relationship with these areas (Table 1). Hunted species at mineral licks include some of the most important game species in Maijuna lands, including paca (C. paca), collared peccary (T. tajacu), whitelipped peccary (T. pecari), red brocket deer (M. americana), and tapir (T. terrestris), all of which are well documented in the literature for visiting mineral licks $[8,9$, 28 . The meat of these species is not only consumed for subsistence, but it is also sold to generate income. Parts of these animals are also used in the making of tourist crafts, traditional medicines, and musical instruments, among other things.

Hunting at mineral licks takes several forms. While walking trails on hunting trips during the day and night, hunters will quickly stop by mineral licks along their routes to see if they can opportunistically catch game species in the lick and to also check for signs of animal activity (i.e., animal tracks). Additionally, hunters will wait alone for several hours at a time at licks with signs of animal activity during both the day and night. They lie in wait at strategic spots above licks with good views and clear shots of the area. At these strategic spots, they

\footnotetext{
${ }^{2}$ All Maijuna terms are in boldface italics. Transcription of Maijuna words was accomplished with the help of Sebastián Ríos Ochoa, a literate and bilingual Maijuna individual, using an orthography developed by Michael et al. [27]. The spelling of Maijuna words was then crosschecked using this same source.
} 
Table 1 Game animals encountered and killed by the Maijuna at mineral licks [20, 24, 25]

\begin{tabular}{|c|c|c|c|c|c|}
\hline Species & Maijuna name & Local name & English name & $\begin{array}{l}\text { Time encountered } \\
\text { (day/night) }\end{array}$ & Use \\
\hline \multicolumn{6}{|l|}{ Birds } \\
\hline Pipile cumanensis & újé & pava & $\begin{array}{l}\text { Blue-throated } \\
\text { piping-guan }\end{array}$ & Day & $\begin{array}{l}\text { Eat, sell (meat), used to make fans for fires } \\
\text { (feathers), adornment (make "paint" from legs) }\end{array}$ \\
\hline \multicolumn{6}{|l|}{ Mammals } \\
\hline Cuniculus paca & $\begin{array}{l}\text { sèmè, } \\
\text { gójébèkò }\end{array}$ & majás & Paca & Night & Eat, sell (meat), tourist crafts (teeth) \\
\hline Alouatta seniculus & jáíki & coto mono & $\begin{array}{l}\text { Red howler } \\
\text { monkey }\end{array}$ & Day & $\begin{array}{l}\text { Eat, sell (meat), tourist crafts (bony pouch } \\
\text { or hyoid bone from throat) }\end{array}$ \\
\hline Coendou prehensilis & tòtò & cashacushillo & $\begin{array}{l}\text { Brazilian } \\
\text { porcupine }\end{array}$ & Night & Eat, tourist crafts (spines) \\
\hline Dasyprocta fuliginosa & máítàkò, kòròmé & añuje & Black agouti & Day & Eat, sell (meat), tourist crafts (teeth) \\
\hline Mazama americana & bósá & venado colorado & Red brocket deer & $\begin{array}{l}\text { Night, rarely } \\
\text { during day }\end{array}$ & $\begin{array}{l}\text { Eat, sell (meat), medicinal (antlers), adornment } \\
\text { of houses (antlers), used to make drums (hide) }\end{array}$ \\
\hline Tapirus terrestris & békit, jáikò & sachavaca & Lowland tapir & Night & $\begin{array}{l}\text { Eat, sell (meat), medicinal (hooves), tourist } \\
\text { crafts (hooves) }\end{array}$ \\
\hline Tayassu pecari & birí, bài & huangana & $\begin{array}{l}\text { White-lipped } \\
\text { peccary }\end{array}$ & Day & $\begin{array}{l}\text { Eat, sell (meat and hide), tourist crafts (teeth), } \\
\text { used to make drums (hide) }\end{array}$ \\
\hline Pecari tajacu & káókwà & sajino & Collared peccary & Day & $\begin{array}{l}\text { Eat, sell (meat and hide), tourist crafts (teeth), } \\
\text { used to make drums (hide) }\end{array}$ \\
\hline
\end{tabular}

will either sit on the ground, make a hunting platform, or string up a hammock between two trees. At night, they lie in wait with their flashlight off listening for animal activity and, according to hunters, they can tell the species entering the lick by the amount and type of noise that it makes as it walks through the mud and standing water to the lick "face." If it is a desirable species, the hunter will then attempt to ambush the animal by turning on their flashlight when it has reached a desirable location in the lick with a clear shot.

Eighty-four mineral licks were identified and had their locations fixed by GPS in the Sucusari River basin during this study. Of these, 43 were regularly visited by hunters during the 11-month period from August 2018 to June 2019. However, during this time period, all hunters did not regularly or equally visit each of these 43 licks. Instead, clear spatial use of 38 of these mineral licks is observed when analyzing the data by family, with each family having distinct mineral licks that they regularly hunt at that others do not enter (Fig. 2). A family, for the sake of this analysis, was defined as a group of individuals united by ties of blood, adoption, or marriage that live in the same household, with some households having multiple hunters that hunt at the same licks. For example, one family during this time period was composed of four individuals, a mother and father with two grown sons (ages 28 and 33) that hunt at the same mineral licks (family 6, Fig. 2). However, the older brother (age 45) of these two hunters lives in a different household with his own wife and children and hunted at totally different mineral licks (family 11, Fig. 2). Although
$100 \%$ of the hunters interviewed during this 11-month period said that they can hunt at whatever mineral lick they want in the Sucusari River basin, including in another family's licks, clear spatial segregation is in fact carried out and observable. Knowledge of mineral licks is passed down through generations, although a hunter marrying into another family will often be taken to the family's licks. This spatial segregation of licks demonstrates the power of traditional resource use rights and strategies. The mineral licks that individual families do hunt at tend to be accessible by trail from either their primary residence or hunting $\operatorname{camp}(\mathrm{s})$, with hunting camps being located in more remote parts of the river basin. It is worth noting that only five mineral licks out of the 43 frequented during this time period were regularly visited by multiple families (Fig. 2). These mineral licks tend to be very close to well-known and regularly used hunting camps and are easier to access.

Due to their use and significance to the Maijuna, mineral licks appear to be a textbook example of what Posey ([31]: 117) referred to as "resource islands." According to Posey [31], "resource islands" are "...areas in the primary forest where specific concentrations of useful plants or animals are found." Through his work with the Kayapó of the Brazilian Amazon, Posey [31] provides several general examples of "resource islands," including sources of palm hearts, palmito and palm nut sources, areas with cane for arrows, hunting areas, and fish concentrations, among others. Conceiving of mineral licks as "resource islands" distributed across the landscape ultimately helps to highlight the importance of properly 


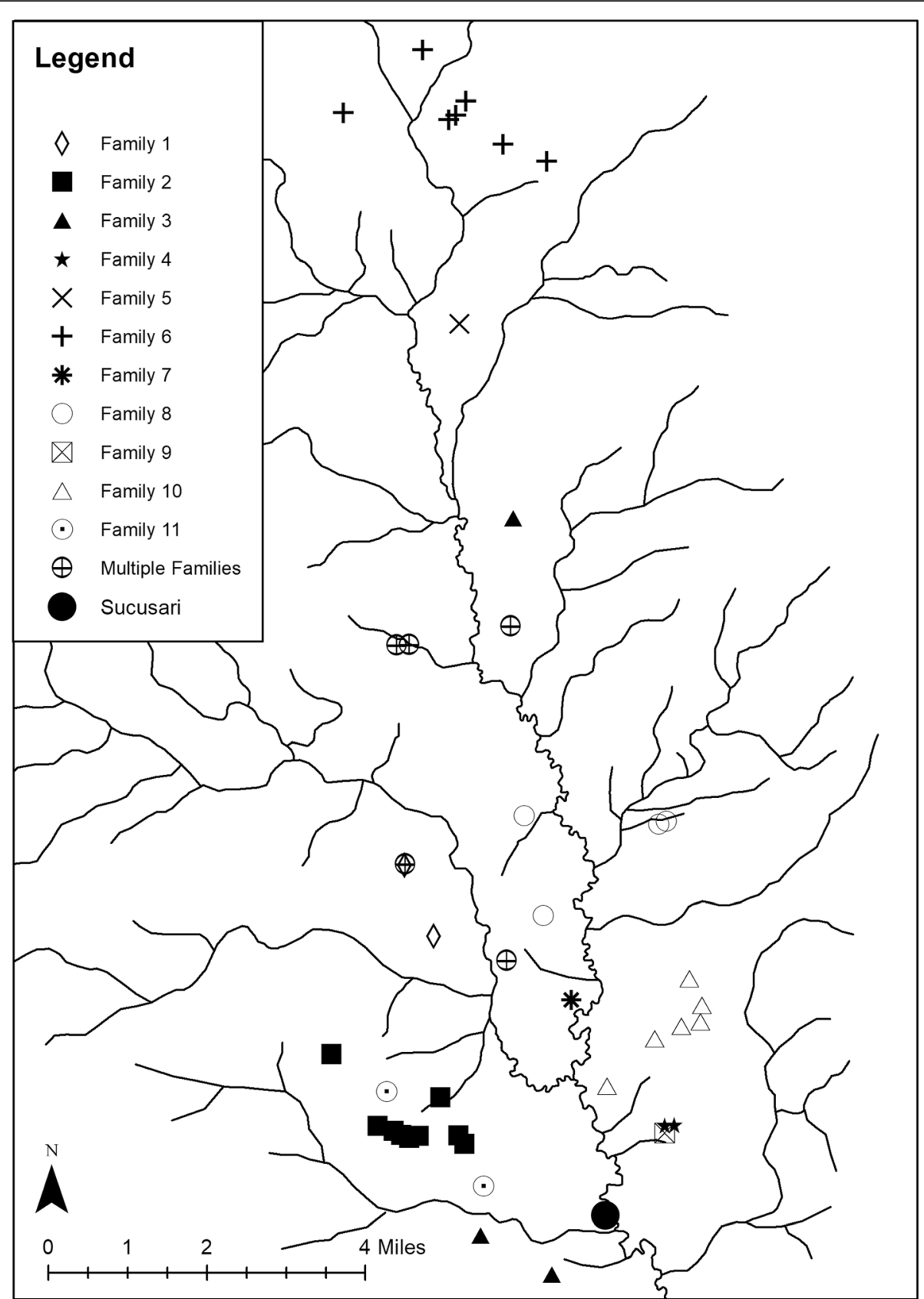

Fig. 2 Forty-three mineral licks visited by hunters in the Sucusari River basin during an 11-month period from August 2018 to June 2019. Mineral licks are divided by family use

managing and conserving these ecologically, culturally, and economically significant areas in Maijuna lands.

\section{Mapping and naming of mineral licks}

A separate participatory mapping project carried out with the Maijuna between 2004 and 2009 (see [24, 25, 32-34]) further highlights the cultural significance of mineral licks. During mapping sessions in all four communities, mineral licks were consistently one of the first bioculturally significant sites that participants mapped highlighting the cultural salience and importance of these areas. In the Sucusari community, after discussing and comparing different ideas [32], mapping participants selected the symbol of a tapir to represent the locations of mineral licks throughout the river basin on their hand-drawn map (Fig. 3). According to participants, the tapir was chosen as the symbol for mineral licks given that it is one of the most culturally important game 


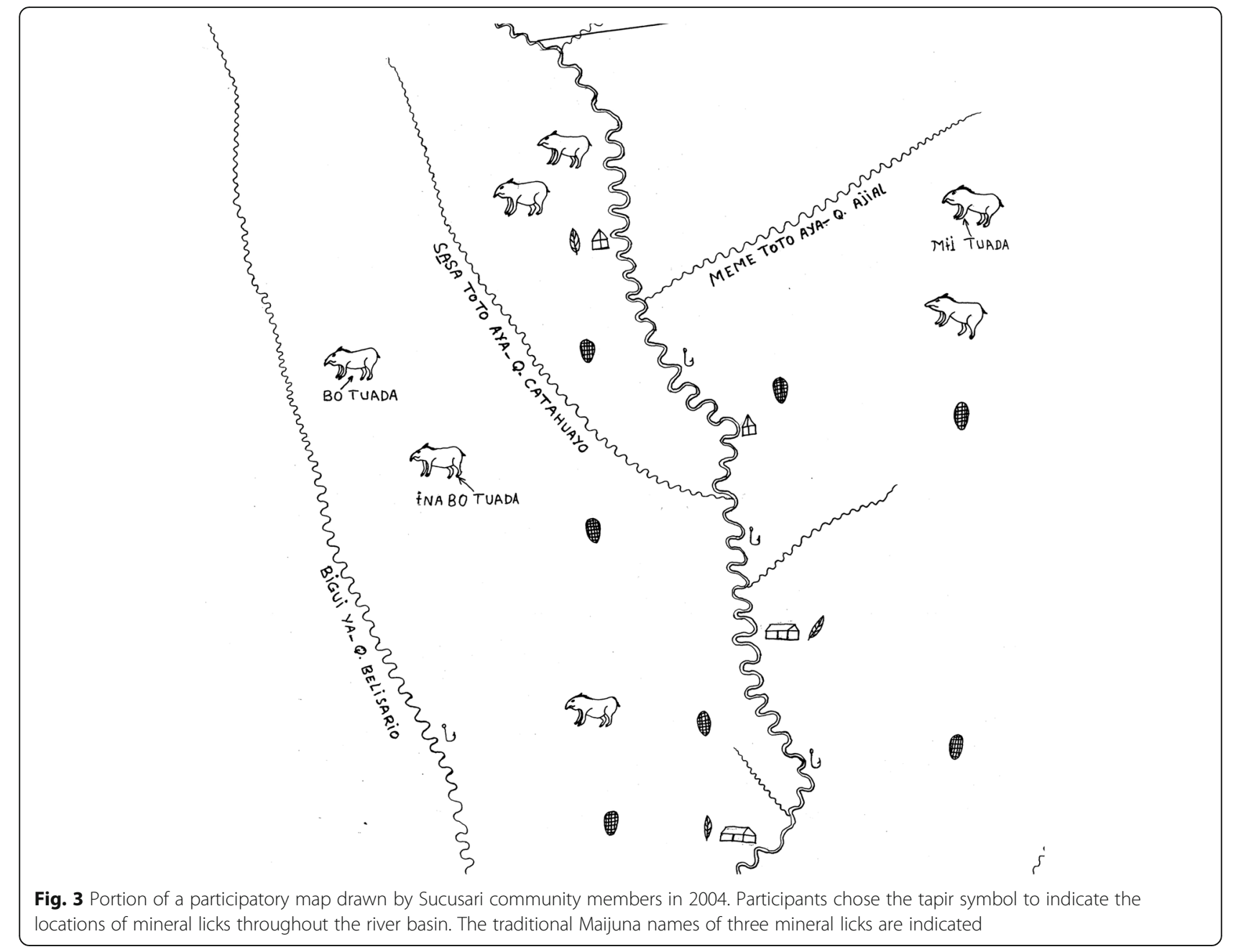

species that visits mineral licks as well as its key role in a traditional story detailing the creation of the first lick (see below).

Out of the 84 mineral licks that were ultimately identified in the Sucusari River basin during this study, 21 have proper names in the Maijuna language. The Maijuna name mineral licks after plants found in or around the area, individuals who hunted there, birds or bats that frequent the lick, general vegetative characteristics, soil type, biting ants present, and the size of the area. The extensive naming of mineral licks further highlights their significance to the Maijuna [20, 24, 25, 35].

\section{Traditional beliefs about mineral licks}

The Maijuna have a very different explanation for why animals visit mineral licks [36]. According to the traditional Maijuna story of the creation of the first tapir, a man named Békitù was seeking revenge on his son-inlaw. He tried to trick him three times, yet his son-in-law outsmarted him each time. After the third time, the son- in-law used his powers as a creator to turn Békitù into a tapir. During this slow transformation, Békitù began to take on more and more qualities of tapirs; he increased in size, made similar noises, began to eat Mauritia flexuosa fruits whole, and became skittish around people. Toward the end of this transformation, Békitù asked his daughter, who was unaware of what was happening, to make masato (a traditional alcoholic beverage made from Manihot esculenta) and bring it to him in the forest. When his daughter returned, he grew increasingly skittish, and eventually refused to come close when she approached, despite her repeated assurances. The exasperated daughter threw her clay pot of masato on the forest floor, where it shattered. Békitù later came and licked up the masato, using his hooves to further mix up the brew and ultimately soften the moist earth, the very first tapir forming the very first mineral lick. In the Maijuna language, the word for masato is ónó and the word for place is bi். A mineral lick, ónóbi, literally means "place of masato," which is why animals are attracted. 
The Maijuna believe that the different animal species that visit mineral licks are there specifically to drink masato.

\section{Changing relationships through time}

First contacted by Jesuit missionaries in 1682, the Maijuna's population declined dramatically due to epidemics, fighting, and then enslavement during the rubber boom. Over the years, Maijuna traditional beliefs, language, and ways of life have been undermined by missionary teachings, patrones $^{3}$, regional society, ill-conceived government policies, and a formal education system that does not value traditional knowledge $[13,37,38]$. This has led to a disconnect with their traditional cultural practices and beliefs, causing a rapid loss of traditional knowledge [13-15, $20,35]$, commonly recognized as acculturation [39].

Due to these realities, the relationship that the Maijuna have with mineral licks has changed considerably over time. For example, they traditionally hunted game animals at mineral licks with spears only during the day. Over the past 100 years, the introduction of shotguns in the Maijuna communities has drastically increased hunting efficiency over traditional methods [40]. The acquisition of incandescent battery-powered flashlights has also facilitated night hunting, allowing the harvesting of nocturnal species at mineral licks. More recently in approximately 2011, the Maijuna began using new, brighter, and more efficient light-emitting diode (LED) flashlights enabling hunters to find and kill prey more easily by increasing the freezing response of many species in spotlights. Maijuna hunters now hunt longer and more frequently at night, in mineral licks and beyond, increasing kill rates of nocturnal species and likely overall harvests [5]. All of these changes in hunting technologies and methods, along with increasing integration into the market economy and subsequent hunting for income generation, have significant conservation and management implications for the hunting of game animals at mineral licks in Maijuna lands.

The Maijuna's changing relationship with mineral licks is also evident in both the naming of and traditional beliefs about licks. Out of the 19 active hunters interviewed for this study in the Maijuna community of Sucusari, only four (21\%) know the names of mineral licks in the Maijuna language. The rest use exclusively Spanish names for mineral licks in the Sucusari River basin, which are sometimes direct translations from the name in Maijuna but most of the time are not. This is not only due to the fact that the Maijuna language is highly endangered and in disuse by younger Maijuna generations [13], but also due to the fact that 9 out of the 19 active

\footnotetext{
${ }^{3}$ Patrones are colonists and their descendants who exploited Indigenous labor to harvest forest resources.
}

hunters (47\%) are not Maijuna and instead are mestizo or Kichwa.

Additionally, although most of the 10 active hunters that are Maijuna know of or have heard the traditional Maijuna story of the creation of the first tapir, only two (ages 65 and 68) know the story in significant detail and are able to tell it in the Maijuna language. This loss of knowledge and traditional beliefs is significant given that traditional stories symbolize unity and the creation of shared bonds for Indigenous people [41]. Most traditional stories help to provide the ethical and moral foundations on which Indigenous cultures are built, document the creation of ancestral lands, and/or disentangle natural events $[42,43]$. These stories reinforce the connection Indigenous people have with nature by highlighting the significance of natural resources for the survival of living beings [44, 45]. The Maijuna traditional story of the creation of the first tapir helps to explain not only the origin of this important game species but also a culturally significant habitat and hunting site that they depend on for sustenance and survival. Additionally, the duality of animals and people in this story may represent the measured use of wildlife through cultural beliefs and traditions, a form of adaptive management of wildlife populations $[46,47]$.

\section{Conclusions}

Through interviews, focus groups, and participatory mapping, we were able to gain a comprehensive understanding of the importance of mineral licks to the Maijuna. Mineral licks are important hunting areas for both subsistence and income generation, and their spatial use across the landscape is determined on the family level. Additionally, the classification and naming of licks as well as traditional beliefs about them further highlights their socio-cultural significance to the Maijuna. Learning all of this information is an essential first step for the development of community-based management plans for mineral licks in the MKRCA that incorporate and account for the multiple cultural and economic needs of the Maijuna while also striving toward ecological sustainability. Next steps could include large-scale monitoring of wildlife use of licks, examining the impacts of hunting at mineral licks on wildlife, and assessing the potential of working with local communities to protect licks as a strategy to manage hunting and conserve wildlife populations. Such management strategies are likely to be similarly useful across the wider Amazon basin, where mineral licks are also of considerable cultural and economic importance as hunting sites $[8,10]$.

Traditional and current Maijuna hunting conventions, in which families maintain exclusive use of selected mineral licks, and exclude access by other hunters, likely reduce the probability of overexploitation, especially where 
hunting is for subsistence rather than commercial purposes. Where Indigenous or local people do not have ownership and control of their hunting grounds, more frequent use of mineral licks by more hunters may occur, increasing the chances of over extraction of wild species. Indigenous land title and the right to restrict access to hunting grounds are key to tackling overhunting in Amazonia.

Although it was found that traditional knowledge and beliefs about mineral licks is in steep decline, the Maijuna still remain deeply connected to their ancestral lands and rely heavily on licks and their associated game species. The role and importance of Indigenous people in conservation is increasing [48-51], which is demonstrated by the key role of the Maijuna in not only the creation of the MKRCA but the ongoing management of this heavily forested and biodiverse area. As communitybased management plans for mineral licks and associated game species are developed for the MKRCA, it is critical that these efforts also address the conservation and revitalization of traditional knowledge and beliefs about these areas. This would help to ensure that both the biological and cultural significance of mineral licks to the Maijuna are being targeted. Given their ecological importance, status as "resource islands," and the traditional beliefs about them, mineral licks in Maijuna lands are complex biocultural systems and need to be managed in a holistic and integrative manner. Management plans that build on and strengthen traditional knowledge and traditional resource use rights and strategies would help to ensure the maintenance of dynamic relationships between mineral licks, their associated biological diversity, and the hunters that use them. Mineral licks are important hunting sites not only in Maijuna lands but also throughout the Amazon basin, and we believe our study provides a much-needed in-depth investigation of how hunters and communities interact with this culturally, biologically, and economically important habitat.

\section{Abbreviations \\ LED: Light-emitting diode; MKRCA: Maijuna-Kichwa Regional Conservation Area; PIC: Prior informed consent}

\section{Acknowledgements}

We would like to thank the Federación de Comunidades Nativas Maijuna (FECONAMAI) and the Sucusari community for their interest and collaboration in this project. A special thanks to Sebastián Ríos Ochoa for his commitment and support throughout the entire research process. We thank OnePlanet, Inc. for invaluable help and support in the field. Additionally, we thank Elizabeth Benson and Forrest Lewis for help in collecting data and Jason Young for producing the map for this paper. We would also like to thank three anonymous reviewers for their time and valuable feedback on this paper.

\section{Authors' contributions}

MG wrote the manuscript with help from BG and MB. All authors helped to design the study, carry out the field research, and analyze/interpret the data. Data collected during this study was supplemented by data that MG has collected during ethnobiological and ethnoecological field research with the
Maijuna since 1999. The authors have read, edited, and approved the final version of the manuscript.

\section{Funding}

George Mason University and OnePlanet, Inc. provided financial support for fieldwork. BG was supported by a Fulbright U.S. Student Research Grant.

\section{Availability of data and materials}

The datasets used and/or analyzed during the current study are available from the corresponding author on reasonable request.

\section{Ethics approval and consent to participate}

Research was conducted with the approval of the Maijuna community of Sucusari as well as the George Mason University Office of Research Integrity and Assurance (ORIA), reference numbers 1288488-2 and 904314-5. Before conducting the interviews, prior informed consent was obtained from the community as well as research participants.

\section{Consent for publication}

All data were published with the prior informed consent of research participants.

\section{Competing interests}

The authors declare that they have no competing interests.

\section{Author details}

${ }^{1}$ School of Integrative Studies, George Mason University, 4400 University Drive, Fairfax, VA 22030, USA. ${ }^{2}$ Environmental Science and Policy, George Mason University, 4400 University Drive, Fairfax, VA 22030, USA. ${ }^{3}$ School of Engineering, Arts, Science and Technology Science, University of Suffolk, Waterfront Building, Neptune Quay, Ipswich IP4 1QJ, UK. Institute for Conservation Research, San Diego Zoo Global, Escondido, CA 92027-9614, USA. ${ }^{5}$ Suffolk Sustainability Institute, Waterfront Building, Neptune Quay, Ipswich IP4 1QJ, UK.

Received: 8 May 2020 Accepted: 22 September 2020

Published online: 07 October 2020

\section{References}

1. Benítez-López A, Alkemade R, Schipper AM, Ingram DJ, Verweij PA, Eikelboom JAJ, et al. The impact of hunting on tropical mammal and bird populations. Science. 2017;356:180-3.

2. Antunes AP, Fewster RM, Venticinque EM, Peres CA, Levi T, Rohe F, et al. Empty forest or empty rivers? A century of commercial hunting in Amazonia. Sci Adv. 2016;2:e1600936.

3. Mesquita GP, Barreto LN. Evaluation of mammals hunting in indigenous and rural localities in Eastern Brazilian Amazon. Ethnobiol Conserv. 2015:4:1-4. https://ethnobioconservation.com/index.php/ebc/article/view/52.

4. Alvard M. Shotguns and sustainable hunting in the Neotropics. Oryx. 1995; 29:58-66.

5. Bowler M, Beirne C, Tobler MW, Anderson M, DiPaola A, Fa JE, et al. LED flashlight technology facilitates wild meat extraction across the tropics. Front Ecol Environ. [cited 2020 Sep 10];n/a. Available from: https://esajournals. onlinelibrary.wiley.com/doi/abs/10.1002/fee.2242.

6. Ayotte JB, Parker KL, Arocena JM, Gillingham MP. Chemical composition of lick soils: functions of soil ingestion by four ungulate species. J Mammal. 2006;87:878-88.

7. Wilson MJ. Clay mineralogical and related characteristics of geophagic materials. J Chem Ecol. 2003;29:1525-47.

8. Tobler MW, Carrillo-Percastegui SE, Powell G. Habitat use, activity patterns and use of mineral licks by five species of ungulate in south-eastern Peru. J Trop Ecol. 2009;25:261-70.

9. Blake JG, Mosquera D, Salvador J. Use of mineral licks by mammals and birds in hunted and non-hunted areas of Yasuní National Park, Ecuador. Anim Conserv. 2013;16:430-7.

10. Montenegro OL. Natural licks as keystone resources for wildlife and people in Amazonia. Gainesville: University of Florida; 2004.

11. Mayor P, El Bizri H, Bodmer RE, Bowler M. Assessment of mammal reproduction for hunting sustainability through community-based sampling of species in the wild. Conserv Biol. 2017;31:912-23. 
12. Tobler MW. The ecology of the lowland tapir in Madre de Dios, Peru: using new technologies to study large rainforest mammals. College Station: Texas A\&M University; 2008.

13. Gilmore MP. The Maijuna: past, present, and future. In Perú: Maijuna, Rapid Biological and Social Inventories Report, 22. Edited by Gilmore MP, Vriesendorp C, Alverson WS, del Campo Á, von May R, López Wong C, Ríos Ochoa S. Chicago: The Field Museum; 2010:226-233.

14. Gilmore MP, Vriesendorp C, Alverson WS, del Campo Á, Von May R, López Wong C, Ríos Ochoa S. Perú: Maijuna. Rapid Biological and Social Inventories Report 22. Chicago: The Field Museum; 2010.

15. Roncal CM, Bowler M, Gilmore MP. The ethnoprimatology of the Maijuna of the Peruvian Amazon and implications for primate conservation. J Ethnobiol Ethnomed. 2018;14:19.

16. Hiraoka M. Changing floodplain livelihood patterns in the Peruvian Amazon. Tsukuba Stud Hum Geogr. 1985;9:243-75.

17. Padoch C. People of the floodplain and forest. In: Deslow JS, Padoch C, editors. People Trop Rain For. Berkeley: University of California Press; 1988. p. 127-40

18. Chibnik M. Risky rivers: the economics and politics of floodplain farming in Amazonia [Internet]. Tucson: University of Arizona Press; 1994. [cited 2012 Dec 20]. Available from: http://books.google.com/books?hl=en\&lr=\&id= egnW8u_-2QUC\&oi=fnd\&pg=PR10\&dq=Risky+rivers:+the+economics+and+ politics+of+floodplain+farming+in+Amazonia. $++\& o t s=$ In7KY8rPRM\&sig= ASPCFgVrfyxQLpqjwqzPwmxVyus.

19. Coomes OT, Ban N. Cultivated plant species diversity in home gardens of an Amazonian peasant village in Northeastern Peru. Econ Bot. 2004;58:420-34.

20. Gilmore MP. An ethnoecological and ethnobotanical study of the Maijuna Indians of the Peruvian Amazon [PhD Thesis]: Miami University; 2005.

21. Vriesendorp C, Foster R. Regional overview, overflight, inventory sites, and human communities visited. In Perú: Maijuna, Rapid Biological and Social Inventories Report, 22. Edited by Gilmore MP, Vriesendorp C, Alverson WS, del Campo A, von May R, López Wong C, Río Ochoa S. Chicago: The Field Museum; 2010:171-5.

22. Marengo J. Climatología de la zona de lquitos, Perú. In Geoecologia y desarrollo Amazonico: estudio integrado en la zona de lquitos, Peru. Edited by Kalliola R, Flores Paitan S. Finland: University of Turku Press; 1998:35-57.

23. Bernard HR. Research methods in anthropology: qualitative and quantitative approaches. Oxford: Rowman \& Littlefield; 2017.

24. Gilmore MP, Young JC. The Maijuna participatory mapping project: mapping the past and the present for the future. In Perú: Maijuna, Rapid Biological and Social Inventories Report, 22. Edited by Gilmore MP, Vriesendorp C, Alverson WS, del Campo A, von May R, López Wong C, Río Ochoa S. Chicago: The Field Museum; 2010:233-242.

25. Gilmore MP, Young JC. The use of participatory mapping in ethnobiological research, biocultural conservation, and community empowerment: a case study from the Peruvian Amazon. J Ethnobiol. 2012;32:6-29.

26. Corbin J, Strauss A. Basics of qualitative research: techniques and procedures for developing grounded theory. Oxford: Sage publications; 2014.

27. Michael L, Beier C, Farmer S, Neely K, Skilton A, Finley G, et al. Diccionario Bilingüe máijiki-castellano y castellano-máíjiki [Internet]. lquitos: Cabeceras Aid Project; 2013. Available from: http://www.cabeceras.org/mai_ore_ diccionario2013.pdf.

28. Molina E, León TE, Armenteras D. Characteristics of natural salt licks located in the Colombian Amazon foothills. Environ Geochem Health. 2014;36:117-29.

29. Fleck DW, Harder JD. Matses Indian rainforest habitat classification and mammalian diversity in Amazonian Peru. J Ethnobiol. 2000;20:1-36.

30. Shepard G, Yu DW, Lizarralde M, Italiano M. Rain forest habitat classification among the Matsigenka of the Peruvian Amazon. J Ethnobiol. 2001:21:1-38

31. Posey DA. A preliminary report on diversified management of tropical forest by the Kayapo Indians of the Brazilian Amazon. Adv Econ Bot. 1984;1:112-26.

32. Young JC, Gilmore MP. The spatial politics of affect and emotion in participatory GIS. Ann Assoc Am Geogr. 2013;103:808-23.

33. Young JC, Gilmore MP. Subaltern empowerment in the Geoweb: tensions between publicity and privacy. Antipode. 2014:46:574-91.

34. Young J, Gilmore M. Participatory uses of geospatial technologies to leverage multiple knowledge systems within development contexts: a case study from the Peruvian Amazon. World Dev. 2017:93:389-401.

35. Gilmore MP, Endress BA, Horn CM. The socio-cultural importance of Mauritia flexuosa palm swamps (aguajales) and implications for multi-use management in two Maijuna communities of the Peruvian Amazon. J Ethnobiol Ethnomed. 2013;9:29.

36. Wingfield A, Gilmore MP. Three days of Masato. ISLE Interdiscip Stud Lit Environ. 2020:27.2:406-15.

37. Bellier I. Los Pueblos Indios En Sus Mitos: Mai-huna [Internet]. Editorial Abya Yala; 1993 [cited 2012 Dec 19]. Available from: http://books.google.com/ books?hl=en\&lr=\&id=GFwRPa38nskC\&oi=fnd\&pg=PA9\&dq=Mai-huna+ Tomo+I\&ots=HVPBVtQ-hh\&sig=IYNN_oOzQpO8J5FXzwTFCbNAUoQ.

38. Bellier I. Los Mai Huna, Tucano occidentales. In: Santos F, Barclay F, editors. Guía Etnográfica Alta Amaz [Internet]. Quito: FLACSO-SEDE; 1994. p. 1-180. [cited 2012 Dec 19]. Available from: http://www.ifeanet.org/publicaciones/ articulo.php?codart=196

39. Reyes-García V, Paneque-Gálvez J, Luz AC, Gueze M, Macía MJ, Orta-Martínez $M$, et al. Cultural change and traditional ecological knowledge. An empirical analysis from the Tsimane'in the Bolivian Amazon. Hum Organ. 2014;73:162

40. Hames RB. A comparison of the efficiencies of the shotgun and the bow in neotropical forest hunting. Hum Ecol. 1979;7:219-52

41. Dallam HE. The growing voice of indigenous peoples: their use of storytelling and rights discourse to transform multilateral development bank policies. Ariz J Int Comp Law. 1991;8:117.

42. Martin GJ. Ethnobotany: a methods manual. London: Chapman \& Hall; 1995.

43. Bennett D. Stepping from the diagram: Australian aboriginal cultural and spiritual values relating to biodiversity. In: Posey DA, editor. Cult Spirit Values Biodivers. London: UNEP and Intermediate Technology Publications; 1999. p. $103-5$.

44. Posey DA, Dutfield G. Beyond intellectual property: toward traditional resource rights for indigenous peoples and local communities. Otawa: International Development Research Centre; 1996.

45. Nakashima D, Roué M. Indigenous knowledge, peoples and sustainable practice. Encycl Glob Environ Change. 2002;5:314-24.

46. Berkes F, Colding J, Folke C. Rediscovery of traditional ecological knowledge as adaptive management. Ecol Appl. 2000;10:1251-62.

47. Berkes F, Folke C, Colding J. Linking social and ecological systems: management practices and social mechanisms for building resilience. Cambridge: Cambridge University Press; 2000.

48. Redford $\mathrm{KH}$, Stearman AM. Forest-dwelling native Amazonians and the conservation of biodiversity: interests in common or in collision? Conserv Biol. 1993;7:248-55.

49. Charnley S, Fischer AP, Jones ET. Integrating traditional and local ecological knowledge into forest biodiversity conservation in the Pacific Northwest. For Ecol Manage. 2007;246:14-28.

50. Prado HM, Murrieta RSS, Adams C, Brondizio ES. Local and scientific knowledge for assessing the use of fallows and mature forest by large mammals in SE Brazil: identifying singularities in folkecology. J Ethnobiol Ethnomed. 2014;10:7.

51. Parry L, Peres CA. Evaluating the use of local ecological knowledge to monitor hunted tropical-forest wildlife over large spatial scales. Ecol Soc. 2015;20 [cited 2020 May 8]. Available from: https://www.jstor.org/stable/262 70233.

\section{Publisher's Note}

Springer Nature remains neutral with regard to jurisdictional claims in published maps and institutional affiliations.

Ready to submit your research? Choose BMC and benefit from

- fast, convenient online submission

- thorough peer review by experienced researchers in your field

- rapid publication on acceptance

- support for research data, including large and complex data types

- gold Open Access which fosters wider collaboration and increased citations

- maximum visibility for your research: over $100 \mathrm{M}$ website views per year

At BMC, research is always in progress.

Learn more biomedcentral.com/submission 